\title{
Preventive risk analysis in the maintenance of patency of the peripherally inserted central catheter
}

\author{
Análise preventiva de riscos na manutenção da permeabilidade \\ de cateter venoso central de inserção periférica \\ Análisis preventivo de riesgos en el mantenimiento de la permeabilidad \\ de catéter venoso central de inserción periférica
}

How to cite this article:

Lima AFC, Saba A, Berger S, Bianchini SS, Berssaneti FT. Preventive risk analysis in the maintenance of patency of the peripherally inserted central catheter. Rev Esc Enferm USP. 2019;53:e03462. DOI: http://dx.doi.org/10.1590/S1980-220X2018011803462

\author{
Antônio Fernandes Costa Lima ${ }^{1}$ \\ Amanda Saba ${ }^{2}$ \\ Simone Berger ${ }^{3}$ \\ Silvia Sauaia Bianchini ${ }^{3}$ \\ Fernando Tobal Berssaneti ${ }^{3}$ \\ ${ }^{1}$ Universidade de São Paulo, Escola de \\ Enfermagem, Departamento de Orientação \\ Profissional, São Paulo, SP, Brazil. \\ ${ }^{2}$ Universidade de São Paulo, \\ Faculdade de Medicina, Hospital das \\ Clínicas, São Paulo, SP, Brazil. \\ ${ }^{3}$ Universidade de São Paulo, Escola \\ Politécnica, Departamento de Engenharia \\ de Produção, São Paulo, SP, Brazil.
}

\begin{abstract}
This theoretical and reflexive study analyzed the risks related to the maintenance of patency of the Peripherally Inserted Central Catheter with the use of saline solution in comparison with saline-filled syringes, through the application of the Healthcare Failure Mode and Effect Analysis - HFMEA. The process was mapped, detailing the failure modes of each step. For the calculation of the Risk Priority Number, the severity and probability of the failure modes were analyzed. This analysis gave rise to the severity and probability matrix. Finally, actions to reduce the failure modes in the maintenance of patency were proposed, considering the use of saline-filled syringes in comparison to the use of saline ampoules. It was verified that the use of saline ampoules is associated with a greater risk, since it requires four stages more than saline-filled syringe does not, increasing the risk of contamination and the level of three different risks, which would result in additional hospital costs. The use of the saline-filled syringe would avoid risks that could negatively affect the patient's health, the nursing professional and the health institution.
\end{abstract}

\section{DESCRIPTORS}

Vascular Access Devices; Central Venous Catheters; Nursing Care; Patient Safety; Cost Control; Quality of Health Care. 


\section{INTRODUCTION}

According to the World Health Organization (WHO), the harms caused by unsafe health care cost trillions of dollars worldwide each year. There are numerous costs associated with poor quality care, resulting from additional hospitalizations, litigation, hospital-acquired infections and unpredicted medical expenses. The considerable loss of resources damages the healthcare setting. Currently in Europe, 15\% of hospital costs can be attributed to occurrences associated with safety failures ${ }^{(1)}$. A report by the British Department of Health estimated that 24,000 health-related accidents occur every year and showed that 150 deaths occur on a weekly basis due to care-related problems that could be avoided ${ }^{(2)}$.

The WHO stresses that the costs associated with preventive actions that increase safety and help eliminating errors are insignificant when compared to the costs arising from adverse events. It is estimated that in the United States alone, between 2010 and 2015, USD 28 Billion have been saved in hospitals in the Medicare health system due to safety improvements implemented ${ }^{(1)}$.

Nowadays, providing safer care in complex and demanding environments is one of the biggest challenges faced by healthcare professionals. In these environments, the main strategies adopted to minimize risks are promoting a safety culture, emphasizing learning and organizational improvement, and developing safer systems and processes that avoid individual accountability for success or failure of care ${ }^{(3)}$.

According to the report To err is human, published almost 2 decades ago by the Institute of Medicine, every year more people die due to medical errors than from car accidents, breast cancer or AIDS. These alarming data served as stimulus for recognizing the need to improve health quality and patient safety. Unfortunately, current data do not indicate a better scenario, according to the WHO, it is estimated that there are 421 million hospitalizations in the world annually, and approximately 42.7 million adverse events occur in patients during these hospitalizations. Conservative estimates point to medical errors as the 14th leading cause of morbidity and mortality across the world, and $50 \%$ of these errors could have been avoided ${ }^{(4)}$.

The science of quality improvement is a valuable alternative to the hostility and confusion that inspections, rewards and punishments can generate. The use of quality tools in health services can lead to substantial improvements; therefore, the science of quality improvement should be included in the curriculum of health staff and managers ${ }^{(5)}$. Aimed at preventing harm to patients, safety management involves detecting problems before they occur, by combining methodologies that detail complex processes, maximizing patient benefits ${ }^{(6)}$.

A tool commonly used in the field of engineering, called Failure Mode and Effect Analysis (FMEA), started being used in healthcare because it is a system of proactive process analysis that can identify vulnerabilities before failures can occur. Therefore, the analysis of procedures related to patient safety, which used to focus on adverse events (AE), has evolved to the analysis of events that have not yet resulted in harm to the patient, that is, it became a preventive analysis. In this context, the Joint Commission on Accreditation of Healthcare Organizations (JCAHO) has included standards for patient safety in its recommendations, emphasizing that organizations should have a preventive risk assessment program, defined and implemented actions to reduce errors in care delivery. The FMEA tool was recommended since it focuses on anticipating problems and addressing hypothetical situations, based on the assumption that failures can occur, even with trained and attentive people ${ }^{(7)}$.

In 2002, authors ${ }^{(8)}$ described the development of the Healthcare Failure Mode and Effect Analysis (HFMEA) in the Department of Veterans Affairs (VA), a tool that adapted FMEA's concepts of severity and probability for healthcare, incorporating the concepts of Hazard Analysis and Critical Points (HACCP) and Root Cause Analysis (RCA) prioritization of adverse events.

The HFMEA is performed through five steps: 1) identification of topic, affected areas or vulnerabilities; 2) assemble of a multidisciplinary team, related to the topic, affected areas or vulnerability; 3 ) description of process and subprocesses flows; 4) conducting a risk analysis, classifying the failure modes according to the severity and probability of each subprocess; 5) definition and implementation of actions to reduce failure modes, identifying responsible individuals and expected outcomes ${ }^{(8)}$. However, since hazard analysis is a subjective process, the variables of this tool should be evaluated according to the characteristics of each context ${ }^{(9)}$.

In different hospital contexts, the establishment and adequate maintenance of vascular access for intravenous therapy (IV) required by patients according to their clinical condition is among the main activities performed by nursing professionals. The Peripherally Inserted Central Catheter (PICC) is a frequently used device in the administration of drugs, blood components and parenteral nutrition ${ }^{(10)}$. When compared to other catheters, it is related to a lower risk of infection ${ }^{(11)}$ and it is becoming popular because of the benefits it brings to $\mathrm{IV}^{(12)}$.

The PICC is classified as a high-cost material (classification A) and is usually strictly controlled in hospitals due to its impact on hospital costs. Therefore, its use is restricted, and its maintenance is rigorous, aiming to avoid the occurrence of AEs and unnecessary costs ${ }^{(13)}$. Catheter occlusion is a common complication that can be caused by drug residues, formation of clots, catheter bending, or inadequate placement. This event may require measures such as anticoagulant infusion or even a new catheterization. If a blocked catheter is used, it may rupture, requiring new tests, procedures and exposure of the patient to diverse risks of various magnitudes. Catheter maintenance can be done by checking the patency and flushing with saline solution ${ }^{(14)}$, a repetitive procedure that must be performed three to five times a day.

In view of the above, this theoretical and reflexive study aims to analyze the risks related to the maintenance of patency of Peripherally Inserted Central Catheters (PICC) with the use of saline solution in comparison to the use of a syringe filled with saline solution, through 
the application of the Healthcare Failure Mode and Effect Analysis (HFMEA).

A group composed of three engineers with theoretical and practical knowledge in the application of the tool in different contexts and two nurses with clinical practice in the insertion and maintenance of PICC in adult patients in a hospitalization unit was responsible for the construction of the HFMEA presented in this study. After detailing the steps, the group mapped the failure modes and assigned severity and probability scores. Then, mitigation and contingency strategies were discussed, recommended and prioritized according to the risk calculation.

\section{APPLICATION OFTHE HFMEA TOOL: ANALYSIS OF FAILURE MODES AS TO EFFECTS (SEVERITY) AND PROBABILITY (OCCURRENCE)}

Through the application of the HFMEA tool ${ }^{(8)}$, the PICC maintenance process with saline ampoules was initially mapped (Figure 1). The absence of indicators that allow the detection of flaws in the steps of the process increases the importance of the preventive risk analysis.

After mapping the process under study, the risk was evaluated according to the severity and probability matrix ${ }^{(8)}$.
Regarding severity, the risk could be rated as grade 4 - catastrophic, when it could lead to death, irreversible health damage or loss of function or organ; grade 3 - severe, when it could cause significant worsening of health status, consequences for health, increased length of hospital stay; grade 2 - moderate, characterized by temporary health impairment that can be easily recovered, with no future consequences for the patient's health and no increase in length of hospitalization; grade 1 - mild, when it does not affect health status, has no future consequences for the patient's health and does not increase the length of hospitalization ${ }^{(8)}$.

Regarding probability, the risk could be categorized as grade 4 - frequent, likely to occur immediately or within a short period of time (several times in a year); grade 3 - occasionally, probably will occur (may happen several times in 1 to 2 years); grade 2 - uncommon, possible to occur sometime (between 2 and 5 years); and grade 1 - rare, unlikely to occur (sometime in 5 to 30 years) ${ }^{(8)}$. For the estimation of risk, the Risk Priority Number is calculated by multiplying severity and probability scores. Risk Priority Number greater than or equal to eight is considered high, and actions to mitigate those risks should be prioritized.
In the nursing station

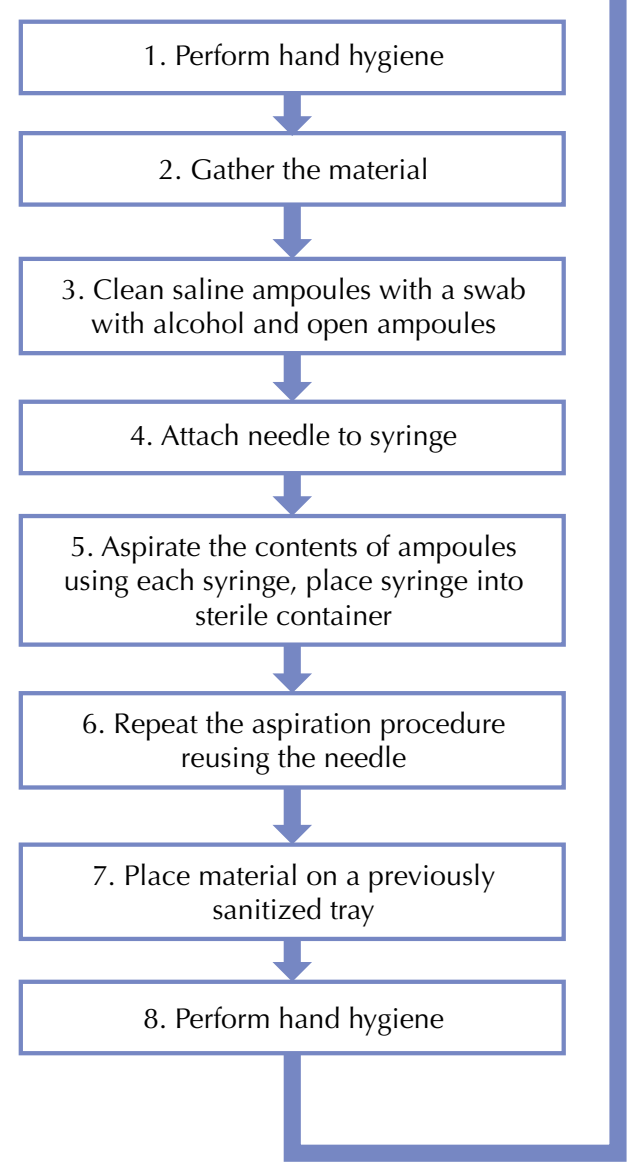

In the patient's room

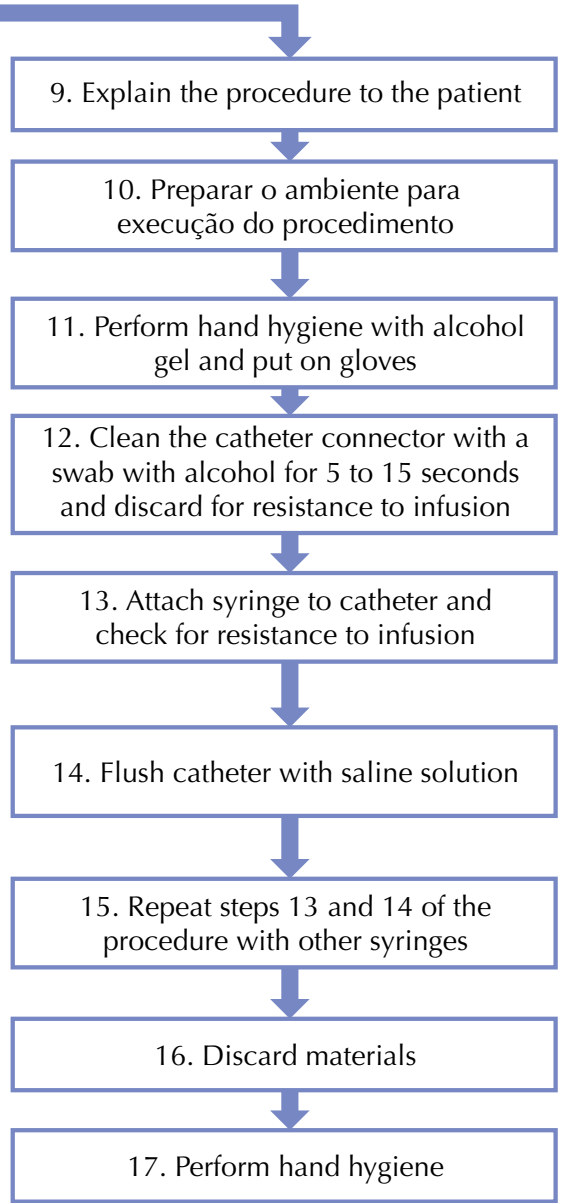

Figure 1 - Peripherally Inserted Central Catheter mapping process with saline ampoules - São Paulo, SP, Brazil, 2018. 
In clinical practice, saline-filled syringes are already available; however, the PICC patency is often maintained with saline ampoules, which require the use of aspiration needles, syringes and ampoules of the solution. This is because the cost of the saline-filled syringe is higher when compared to the cost of the needle, syringes and saline ampoules routinely used. When discussing flushing and maintenance of the peripheral catheter, which is similar to the maintenance of the PICC, the National Sanitary Surveillance Agency (ANVISA - Agência Nacional de Vigilância Sanitária) recommends the use of saline-filled syringes to reduce bloodstream infection and optimize the time spent by the healthcare team ${ }^{(15)}$, making the process more agile and secure.

In order to compare the risks related to these two possibilities and to enable the PICC maintenance process, the steps, failure modes, potential effects, severity (S), probability (P) and Risk Priority Number (RPN) were simulated, along with proposed actions to reduce failure modes, as presented in Charts 1 and 2.

Finally, a probability versus severity matrix was constructed (Chart 3) comparing the use of saline ampoules and saline-filled syringes.

The analysis of the matrix showed a lower risk associated with the PICC patency maintenance with saline-filled syringes, as steps 3, 4, 5 and 6 would no longer exist, and the risks associated with steps 2,14 and 15 would be less critical. Step 2 is gathering materials. The use of the salinefilled syringe reduces the likelihood of lack of materials and consequently, the associated RPN is also reduced. Steps 14 and 15 are related to the process of flushing with saline and repeating operations. One of the hazards is the use of a syringe with inadequate thickness or infusion with insufficient volume in this repetitive activity, which is minimized when using a pre-filled saline syringe.

Chart 1 - Risk analysis of Peripherally Inserted Central Catheter (PICC) maintenance with saline ampoules and saline-filled syringes in the nursing station - São Paulo, SP, Brazil, 2018.

\begin{tabular}{|c|c|c|c|c|c|c|c|c|}
\hline \multirow{2}{*}{ Failure mode by step } & \multirow{2}{*}{ Potential effects } & \multicolumn{3}{|c|}{$\begin{array}{c}\text { Saline } \\
\text { ampoules }\end{array}$} & \multicolumn{3}{|c|}{$\begin{array}{l}\text { Saline-filled } \\
\text { syringes }\end{array}$} & \multirow{2}{*}{ Proposed actions to reduce failure mode } \\
\hline & & S & $\mathbf{P}$ & RPN & S & $\mathbf{P}$ & RPN & \\
\hline \multicolumn{8}{|l|}{ Step 1 - Perform hand hygiene } & \multirow{2}{*}{$\begin{array}{l}\text { Periodic awareness-raising activities and } \\
\text { training on hand hygiene }\end{array}$} \\
\hline Inadequate hygiene & Cross contamination & 3 & 1 & 3 & & alter & & \\
\hline \multicolumn{8}{|l|}{ Step 2 - Gather the material } & \multirow{2}{*}{$\begin{array}{l}\text { Adequate provision of materials, request for } \\
\text { material; notification of occurrences related to } \\
\text { inadequate materials for the procedure }\end{array}$} \\
\hline $\begin{array}{l}\text { Materials not available, or } \\
\text { insufficient quantity }\end{array}$ & $\begin{array}{l}\text { PICC breakage due to use } \\
\text { of inadequate syringe, } \\
\text { loss of catheter }\end{array}$ & 4 & 2 & 8 & 4 & 1 & 4 & \\
\hline \multicolumn{8}{|c|}{ Step 3 - Clean saline ampoules with a swab with alcohol and open ampoules } & \multirow{8}{*}{$\begin{array}{l}\text { Periodic training on maintenance of PICC } \\
\text { patency, acquisition of saline-filled syringes, } \\
\text { training on the proper use of the saline-filled } \\
\text { syringe (steps } 3 \text { to 6) }\end{array}$} \\
\hline Inadequate hygiene & $\begin{array}{l}\text { Contamination of } \\
\text { material }\end{array}$ & 1 & 3 & 3 & & haz: & & \\
\hline \multicolumn{8}{|c|}{ Step 4 - Attach needle to syringe } & \\
\hline $\begin{array}{l}\text { Work accident involving the } \\
\text { nursing professional }\end{array}$ & $\begin{array}{l}\text { Delayed flushing or } \\
\text { non-accomplishment of } \\
\text { procedure }\end{array}$ & 3 & 2 & 6 & & haz: & & \\
\hline \multicolumn{8}{|c|}{ Step 5 - Aspirate the contents of ampoules using each syringe, place syringe into sterile container } & \\
\hline $\begin{array}{l}\text { Partial or insufficient } \\
\text { aspiration of saline solution; } \\
\text { syringe placed outside } \\
\text { sterile packaging }\end{array}$ & $\begin{array}{l}\text { Contamination of } \\
\text { material }\end{array}$ & 2 & 1 & 2 & & haz & & \\
\hline \multicolumn{8}{|c|}{ Step 6 - Repeat the aspiration procedure reusing the needle } & \\
\hline $\begin{array}{l}\text { Partial or insufficient } \\
\text { aspiration of saline solution; } \\
\text { syringes placed outside } \\
\text { sterile packaging }\end{array}$ & $\begin{array}{l}\text { Contamination of } \\
\text { material }\end{array}$ & 2 & 3 & 6 & & haz: & & \\
\hline \multicolumn{8}{|c|}{ Step 7 - Place material on a previously sanitized tray } & \multirow{2}{*}{$\begin{array}{l}\text { Previous verification of the materials required } \\
\text { for the procedure according to the guidelines } \\
\text { of the institution }\end{array}$} \\
\hline $\begin{array}{l}\text { Materials not available, or } \\
\text { insufficient quantity }\end{array}$ & $\begin{array}{l}\text { Contamination of } \\
\text { material }\end{array}$ & 1 & 3 & 3 & & alter & & \\
\hline \multicolumn{8}{|l|}{ Step 8 - Perform hand hygiene } & \multirow{2}{*}{$\begin{array}{l}\text { Periodic awareness-raising activities and } \\
\text { training on hand hygiene }\end{array}$} \\
\hline Inadequate hygiene & Cross contamination & 3 & 2 & 6 & \multicolumn{3}{|c|}{ Unaltered } & \\
\hline
\end{tabular}


Chart 2 - Risk analysis of Peripherally Inserted Central Catheter (PICC) maintenance with saline ampoules and saline-filled syringes in the patient's room - São Paulo, SP, Brazil, 2018.

\begin{tabular}{|c|c|c|c|c|c|c|c|c|}
\hline \multirow{2}{*}{ Failure mode by step } & \multirow[t]{2}{*}{ Potential effects } & \multicolumn{3}{|c|}{$\begin{array}{c}\text { Saline } \\
\text { ampoules }\end{array}$} & \multicolumn{3}{|c|}{$\begin{array}{l}\text { Saline-filled } \\
\text { syringes }\end{array}$} & \multirow{2}{*}{ Proposed actions to reduce failure mode } \\
\hline & & S & $\mathbf{P}$ & RPN & $\mathbf{S}$ & $\mathbf{P}$ & RPN & \\
\hline \multicolumn{8}{|c|}{ Step 9 - Explain the procedure to the patient } & \multirow{2}{*}{$\begin{array}{l}\text { Previously orient patients on the importance of } \\
\text { being informed about their treatment in order } \\
\text { to improve quality and safety of the procedure }\end{array}$} \\
\hline $\begin{array}{l}\text { No explanation or poor } \\
\text { explanation }\end{array}$ & $\begin{array}{l}\text { Uninformed patient who } \\
\text { can't provide alerts and } \\
\text { feedback }\end{array}$ & 1 & 3 & 3 & \multicolumn{3}{|c|}{ Unaltered } & \\
\hline \multicolumn{8}{|c|}{ Step 10 - Prepare the environment for the procedure } & \multirow[b]{2}{*}{$\begin{array}{l}\text { Periodic training on the maintenance of PICC } \\
\text { patency with saline solution and/or saline-filled } \\
\text { syringe }\end{array}$} \\
\hline $\begin{array}{l}\text { Patient in inadequate } \\
\text { position, poor lighting, } \\
\text { absence of containers for } \\
\text { material disposal }\end{array}$ & $\begin{array}{l}\text { Delay in the procedure, } \\
\text { inappropriate waste } \\
\text { disposal }\end{array}$ & 3 & 1 & 3 & \multicolumn{3}{|c|}{ Unaltered } & \\
\hline \multicolumn{8}{|c|}{ Steps 11 and 17 - Perform hand hygiene with alcohol gel and put on gloves } & \multirow{2}{*}{$\begin{array}{l}\text { Periodic awareness-raising activities and } \\
\text { training on hand hygiene and correct use of } \\
\text { gloves }\end{array}$} \\
\hline $\begin{array}{l}\text { Inadequate hygiene, } \\
\text { inappropriate use of gloves }\end{array}$ & Cross contamination & 3 & 1 & 3 & \multicolumn{3}{|c|}{ Unaltered } & \\
\hline \multicolumn{8}{|c|}{$\begin{array}{l}\text { Step } 12 \text { - Clean the catheter connector with a swab with alcohol for } 5 \text { to } 15 \text { seconds and discard } \\
\text { swab in trash }\end{array}$} & \multirow[b]{2}{*}{$\begin{array}{l}\text { Periodic training on the prevention of } \\
\text { bloodstream infection; double-checking } \\
\text { actions involving the patient }\end{array}$} \\
\hline $\begin{array}{l}\text { Absent or insufficient } \\
\text { disinfection }\end{array}$ & $\begin{array}{l}\text { PICC contamination, } \\
\text { bloodstream infection, } \\
\text { increased length of } \\
\text { hospital stay }\end{array}$ & 3 & 3 & 9 & & 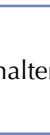 & & \\
\hline \multicolumn{8}{|c|}{ Step 13 - Attach syringe to catheter and check for resistance to infusion } & \multirow{2}{*}{$\begin{array}{l}\text { Periodic training on the maintenance of PICC } \\
\text { patency with saline solution and/or saline-filled } \\
\text { syringe; double-checking actions; notification } \\
\text { of cases of abnormal resistance to the PICC } \\
\text { team }\end{array}$} \\
\hline $\begin{array}{l}\text { No verification or wrong } \\
\text { verification, step not } \\
\text { performed as recommended }\end{array}$ & $\begin{array}{l}\text { PICC occlusion, rupture } \\
\text { of catheter tip, embolism, } \\
\text { increased length of } \\
\text { hospital stay, risk of death }\end{array}$ & 4 & 2 & 8 & & nalte & & \\
\hline \multicolumn{8}{|c|}{ Step 14 - Flush catheter with saline solution } & \multirow[b]{2}{*}{$\begin{array}{l}\text { Exclusive use of the saline-filled syringe; } \\
\text { periodic training on the maintenance of PICC } \\
\text { patency }\end{array}$} \\
\hline $\begin{array}{l}\text { Use of syringe with wrong } \\
\text { thickness and/or inadequate } \\
\text { infusion of volume of saline } \\
\text { solution }\end{array}$ & $\begin{array}{l}\text { PICC occlusion, } \\
\text { rupture of catheter tip, } \\
\text { embolism, increased } \\
\text { length of hospital stay, } \\
\text { re-examination, new } \\
\text { catheterism required }\end{array}$ & 4 & 1 & 4 & 1 & 1 & 1 & \\
\hline \multicolumn{8}{|c|}{ Step 15 - Repeat steps 13 and 14 of the procedure with the other syringes } & \multirow[b]{2}{*}{$\begin{array}{l}\text { Exclusive use of the saline-filled syringe; } \\
\text { periodic training on the maintenance of PICC } \\
\text { patency }\end{array}$} \\
\hline $\begin{array}{l}\text { Contamination of syringe, } \\
\text { use of syringe with wrong } \\
\text { thickness and/or inadequate } \\
\text { infusion of volume of saline } \\
\text { solution }\end{array}$ & $\begin{array}{l}\text { PICC occlusion, } \\
\text { rupture of catheter tip, } \\
\text { embolismn increased } \\
\text { length of hospital stay, } \\
\text { risk of death, infection }\end{array}$ & 4 & 2 & 8 & 4 & 1 & 4 & \\
\hline \multicolumn{8}{|l|}{ Step 16 - Discard materials } & \multirow[b]{2}{*}{$\begin{array}{l}\text { Periodic awareness-raising activities and } \\
\text { training on appropriate waste disposal }\end{array}$} \\
\hline $\begin{array}{l}\text { Materials discarded in } \\
\text { inappropriate places/ } \\
\text { containers }\end{array}$ & Cross contamination & 3 & 1 & 3 & \multicolumn{3}{|c|}{ Unaltered } & \\
\hline
\end{tabular}

Chart 3 - Probability versus severity matrix related to the Peripherally Inserted Central Catheter (PICC) maintenance process with saline ampoules and with saline-filled syringes - São Paulo, SP, Brazil, 2018.

\begin{tabular}{|c|c|c|c|c|c|c|c|c|c|}
\hline \multirow[b]{2}{*}{ Probability } & \multicolumn{4}{|c|}{ Severity - Saline ampoules } & \multirow[b]{2}{*}{ Probability } & \multicolumn{4}{|c|}{ Severity - Saline-filled syringes } \\
\hline & $\begin{array}{c}\text { Catastrophic } \\
4\end{array}$ & $\begin{array}{c}\text { Severe } \\
3\end{array}$ & $\begin{array}{c}\text { Moderate } \\
2\end{array}$ & $\begin{array}{c}\text { Mild } \\
1\end{array}$ & & $\begin{array}{c}\text { Catastrophic } \\
4\end{array}$ & $\begin{array}{c}\text { Severe } \\
3\end{array}$ & $\begin{array}{c}\text { Moderate } \\
2\end{array}$ & $\begin{array}{c}\text { Mild } \\
1\end{array}$ \\
\hline $\begin{array}{l}\text { Frequent } \\
\qquad 4\end{array}$ & & & & & $\begin{array}{l}\text { Frequent } \\
\qquad 4\end{array}$ & & & & \\
\hline $\begin{array}{c}\text { Occasionally } \\
3\end{array}$ & & & 6 & & $\begin{array}{c}\text { Occasionally } \\
3\end{array}$ & & & & \\
\hline $\begin{array}{c}\text { Uncommon } \\
2\end{array}$ & 13215 & 8 & & & $\begin{array}{c}\text { Uncommon } \\
2\end{array}$ & 13 & 8 & & \\
\hline $\begin{array}{c}\text { Rare } \\
1\end{array}$ & 14 & & 5 & & $\begin{array}{c}\text { Rare } \\
1\end{array}$ & 215 & & & 14 \\
\hline
\end{tabular}

Legend: Risk activities not changed; $\square$ Risk activities changed with the use of saline solution; $\square$ Additional activities using saline ampoules 


\section{PERSPECTIVES AND POSSIBILITIES OF USING} THE HFMEA TOOL

The hazard analysis through the HFMEA tool evidenced the priority mitigation actions for the intolerable hazards of the use of saline ampoules and saline-filled syringes. The mitigation actions emphasized were: periodic training of nursing professionals; double-checking actions involving the patient; patient's knowledge about the treatment, their behavior and manifestation of agreement; and notification of a professional member of the PICC team in situations of greater specificity/complexity.

Regarding the periodic training of nursing professionals on the maintenance of PICC patency, prevention of bloodstream infection, hand hygiene and correct use of gloves, it is emphasized that educational programs should be continuous and based on the best scientific evidence available, in order to promote quality and safety in the provision of services. In a teaching hospital in Paraná, training on PICC increased glove use among nurses handling the catheter from $44 \%$ to $75 \%{ }^{(16)}$, showing that after improving the knowledge about the care with the device, the care practice also improved.

On the other hand, it is worth emphasizing that education and training efforts are usually focused on teaching professionals to do "the right thing", assuming that training will stop people from making mistakes. The processes are designed based on the premise that nothing will go wrong; when something does go wrong, the individuals involved are punished, trained again, penalized. This premise is mistaken; errors can be reduced by continuous process analysis within a strong security culture promoted by leadership through proactive risk analysis ${ }^{(9)}$.

Thus, regarding the procedure of maintenance of PICC patency, the availability of saline-filled syringes provides greater agility in the material gathering stage. Consequently, it is associated with a lower error probability. In addition, a more agile process would allow the adoption of other mitigation actions, such as double-checking actions with the participation of the patient, as it would not unreasonably compromise nursing professionals' time. This aspect should be considered, since professionals are exposed to excessive overload in different care contexts, along with presenteeism and decrease in the number of employees due to absenteeism, lack of hiring and/or dismissal processes.

A systematic review ${ }^{(17)}$ verified that the participation of patients and appreciation of their experiences is positively related to effective clinical outcomes and safety, improved treatment adherence, preventive care and better use of resources, with repercussions on the hospitalization process and on the length of hospital stay.

It should be emphasized that contingency actions to reduce the impacts of $\mathrm{AE}$ related to saline ampoules or saline-filled syringes should involve, whenever necessary, the immediate notification of the PICC team to perform specific maneuvers to clear the catheter, such as the decision to remove the device, transferring the PICC, taking new radiographs and requesting an evaluation from the medical team for definition of complementary procedures.
In this perspective, a study ${ }^{(13)}$ described AEs during PICC patency maintenance that required life-saving maneuvers. The study emphasized the inestimable value of human life, the possibility of permanently compromising the image of the institution and the psychological consequences for the professional involved in the $\mathrm{AE}$.

Corroborating the favorable results obtained in this study, other studies ${ }^{(18-20)}$ have verified the applicability of the HFMEA tool in different hospital units. In a Hospitalization Unit, the application of this tool allowed the identification and mitigation of risks related to the administration of anti-infective drugs (unnecessary or inappropriate use, omission and wrong time errors). The causes of failures were grouped in organizational processes management (routines, protocols, continuing education, work overload); human resources (knowledge deficit, lack of skills, lack of attention) and physical and material structure. The HFMEA helped to prioritize actions to increase reliability in the process. Actions were related to continuing education, replanning and redistribution of activities and elaboration of protocols and checklists ${ }^{(18)}$.

Another study using the HFMEA addressed the hazards in a Neonatal Intensive Care Unit, where nurses performed complex activities with many requirements and stages, and where interruptions and distractions could lead to a series of AEs. Based on the root cause analysis, recommendations were grouped into six areas (education, facilities, equipment, technologies, processes and staff), and actions were prioritized according to the analysis of risks ${ }^{(19)}$.

In a Pediatric Emergency Unit, researchers calculated the failure modes in the blood transfusion process using the HFMEA. The failure modes were grouped into care errors (errors of judgment, errors in execution), communication problems and administrative problems. The failure modes were also grouped into levels: emergency, urgency, programming and monitoring. Actions were elaborated according to the analysis of risks: elimination, control or acceptance ${ }^{(20)}$.

In the present study, through the use of the HFMEA tool, it was possible to qualitatively evaluate the risks related to the maintenance of PICC patency with saline ampoules or saline-filled syringes. The maintenance of PICC patency with saline ampoules is associated with a greater risk for the patience, since it requires four stages that the saline-filled syringe does not, increasing the risk of contamination and the level of three different hazards. The risks related to the flushing procedure can increase the length of hospital stay due to complications, necessity of removal of PICC and insertion of a new device, repetition of radiographies or other tests. Consequently, this may increase hospital costs.

\section{FINAL CONSIDERATIONS}

The application of the HFMEA tool showed that the use of the saline-filled syringe would avoid greater risks in comparison with the use of saline ampoules, which could negatively affect the patient's health, the nursing professional and the image of the health institution, resulting in tangible and intangible additional costs. 
Future studies should analyze the costs of using saline ampoules, including manpower and indirect costs, compared to the costs of saline-filled syringes in good practice institutions. The costs of mapped consequences and mitigation and contingency actions are also gaps to be investigated in new studies.

\section{RESUMO}

Este estudo teórico-reflexivo analisou os riscos relacionados ao processo de manutenção da permeabilidade do Cateter Central de Inserção Periférica, com o uso de solução salina em comparação com seringa preenchida com solução salina, por meio da aplicação da ferramenta Healthcare Failure Mode and Effect Analysis - HFMEA. O processo foi mapeado detalhando-se os modos de falha de cada etapa. Para o cálculo do Risk Priority Number, analisaram-se os modos de falha quanto à severidade e à probabilidade. A partir dessa análise, elaborou-se a matriz de severidade e probabilidade. Por fim, evidenciaram-se propostas de ações para redução dos modos de falhas no processo de manutenção da permeabilidade caso fosse utilizada a seringa preenchida em comparação com a utilização de ampolas de solução salina. Verificou-se que o uso de ampolas de solução salina representa maior risco para o paciente, visto que demanda quatro etapas a mais que do que a manutenção com seringa preenchida, aumentando o risco de contaminação e a criticidade de três perigos, o que resultaria em custos hospitalares adicionais. $\mathrm{O}$ uso da seringa preenchida evitaria riscos maiores, os quais poderiam repercutir, desfavoravelmente, na saúde do paciente, no profissional de enfermagem e na instituição de saúde.

\section{DESCRITORES}

Dispositivos de Acesso Vascular; Cateteres Venosos Centrais; Cuidados de Enfermagem; Segurança do Paciente; Controle de Custos; Qualidade da Assistência à Saúde.

\section{RESUMEN}

Este estudio teórico reflexivo analizó los riesgos relacionados con el proceso de mantenimiento de la permeabilidad del Catéter Central de Inserción Periférica, con el empleo de solución salina en comparación con jeringa rellena de solución salina, mediante la aplicación de la herramienta Healthcare Failure Mode and Effect Analysis - HFMEA. El proceso fue mapeado detallándose los modos de falla de cada etapa. Para el cómputo del Risk Priority Number, se analizaron los modos de falla en cuanto a la severidad y la probabilidad. Mediante dicho análisis, se confeccionó la matriz de severidad y probabilidad. Por fin, se evidenciaron las propuestas de acciones para la reducción de los modos de fallas en el proceso de mantenimiento de la permeabilidad en el caso de utilizarse la jeringa en comparación con la utilización de ampollas de solución salina. Se verificó que el uso de ampollas de solución salina representa mayor riesgo para el paciente, visto que demanda cuatro etapas más que el mantenimiento con jeringa rellena, aumentando el riesgo de contaminación y la criticidad de tres peligros, lo que resultaría en costos hospitalarios adicionales. El uso de la jeringa rellena evitaría riesgos mayores, los que podrían repercutir desfavorablemente en la salud del paciente, en el profesional enfermero y el centro sanitario.

\section{DESCRIPTORES}

Dispositivos de Acceso Vascular; Catéteres Venosos Centrales; Atención de Enfermería; Seguridad del Paciente; Control de Costos; Calidad de la Atención de Salud.

\section{REFERENCES}

1. World Health Organization. Patient safety: making health care safer [Internet]. Geneva: WHO; 2017 [cited 2017 Dec 13]. Available from: http://apps.who.int/iris/bitstream/10665/255507/1/WHO-HIS-SDS-2017.11-eng.pdf?ua=1

2. United Kimgdom. Department of Health and Social Care. Draft Health Service Safety Investigations Bill [Internet]. London; 2017 [cited 2017 Dec 10]. Available from: https://www.gov.uk/government/publications/health-service-safety-investigations-bill

3. Brasil. Ministerio da Saude. Portaria n. 529, de 1 de abril de 2013. Institui o Programa Nacional de Segurança do Paciente [Internet]. Brasília; 2013 [citado 2017 dez. 20]. Disponível em: http://bvsms.saude.gov.br/bvs/saudelegis/gm/2013/prt0529_01_04_2013.html

4. World Health Organization. Patient safety [Internet]. Geneva: WHO; 2018 [cited 2018 Sept 01]. Available from: http://www.who.int/ news-room/facts-in-pictures/detail/patient-safety

5. Berwick DM. Era 3 for medicine and health care. JAMA. 2016;315(13):1329-30. DOI: 10.1001/jama.2016.1509

6. Faiella G, Parand A, Franklin BD, ChanaP, Cesarelli M, Stanton NA, et al. Expanding healthcare failure mode and effect analysis: a composite proactive risk analysis approach. Reliabil Eng Syst Safety. 2018;169:117-26. DOI: https://doi.org/10.1016/j.ress.2017.08.003

7. Joint Commission International; Joint Comission Resources. Failure mode and effects analysis in health care: proactive risk reduction. $3^{\text {rd }}$ ed. Illinois; 2010.

8. DeRosier J, Stalhandske E, Bagian JP, Nudell T; Joint Comission. Using health care failure mode and effect analysis: the VA National Center for patient safety's prospective risk analysis system. Jt Comm J Qual Improv. 2002 [cited 2017 Nov 20];27(5):248-67. Available from: https:// www.patientsafety.va.gov/docs/hfmea/HFMEA_JQI.pdf

9. Rah JE, Manger RP, Yock AD, Kim G-Y. A comparison of two prospective risk analysis methods: traditional FMEA and a modified healthcare FMEA. Med Phys. 2016;43(12):6347-53. DOI: http://doi.wiley.com/10.1118/1.4966129

10. Lo Priore E, Fliedner M, Heverhagen JT, Novak JMU. The role of a surveillance programme for intro-ducing peripherally inserted central catheters: a 2-year observational study in an academic hospital. Swiss Med Wkly. 2017;147:w14441. DOI: 10.4414/smw.2017.14441

11. Chopra V, O'Horo JC, Rogers MAM, Maki DG, Safdar N. The risk of bloodstream infection associated with peripherally inserted central catheters compared with central venous catheters in adults: a systematic review and meta-analysis. Infect Control Hosp Epidemiol. 2013;34(9):908-18. DOI: 10.1086/671737

12. Martins C, Oselame GB, Neves EB. Cateter central de inserção periférica: revisão sistemática. Rev Bras Ciênc Saúde [Internet]. 2016 [citado 2017 mar. 1];14(47). Available from: http://seer.uscs.edu.br/index.php/revista_ciencias_saude/article/view/3358 
13. Sá JS de, Bezerra ALQ, Tobias GC, Paranaguá TTB. Eventos adversos na utilização do cateter venoso central de inserção periférica em hospital público. J Nurs UFPE online [Internet]. 2015 [citado 2017 jan. 15];9(8):8802-9. Disponível em: https://periodicos.ufpe.br/revistas/ revistaenfermagem/article/view/10664

14. Infusion Nurses Society. Infusion nursing standards of practice. J Infus Nurs. 2006;29(1 Suppl):S1-92.

15. Brasil. Ministério da Saúde; Agência Nacional de Vigilância Sanitária. Medidas de Prevenção de Infecção relacionada à Assistência à Saúde. Brasília: ANVISA; 2017.

16. Mingorance P, De Lazzari LSM, Johann DA, Reichembach Danski MT. Avaliação de diretriz clínica para cuidados com cateter central de inserção periférica em neonatos. J Nurs UFPE online [Internet]. 2013 [citado 2017 jan. 15];7(6):4364-9. Disponível em: https://periodicos. ufpe.br/revistas/revistaenfermagem/article/view/11675

17. Doyle C, Lennox L, Bell D. A systematic review of evidence on the links between patient experience and clinical safety and effectiveness. BMJ Open [Internet]. 2013 [cited 2017 Nov 28];3(1):e001570. Available from: https://www.ncbi.nlm.nih.gov/pmc/articles/PMC3549241/

18. Silva AEBC, Cassiani SHB. Prospective risk analysis of the anti-infective medication administration process. Rev Latino Am Enfermagem [Internet]. 2013;21(n.spe):233-41. Available from: http://www.scielo.br/scielo.php?script=sci_arttext\&pid=S0104-11692013000700029\&In $\mathrm{g}=\mathrm{en} \& \mathrm{nrm}=$ iso\&tlng=en

19. Zhang B, LaFleur EA, Ballweg DD, Mulholland KL, Wild JA, Shedenhelm HJ, et al. Use of healthcare Failure Mode and Effect Analysis (HFMEA) to quantify risks of the human milk feeding process. J Nurs Care Qual. 2014;29(1):30-7. DOI: 10.1097/NCQ.0b013e3182a61555

20. Dehnavieh R, Ebrahimipour H, Molavi-Taleghani Y, Vafaee-Najar A, Hekmat SN, et al. Proactive risk assessment of blood transfusion process, in pediatric emergency, using the Health care Failure Mode and Effects Analysis (HFMEA). Glob J Health Sci [Internet]. 2014 [cited 2017 Nov 28];7(1):322-31. Available from: https://www.ncbi.nlm.nih.gov/pmc/articles/PMC4796474/

Financial support

This study was financed in part by the Coordenação de Aperfeiçoamento de Pessoal de Nível Superior - Brasil (CAPES) - Finance Code 001. 